\title{
Hydrologic Pulses and Remaining Natural Vegetation in Jaú and Jacaré-Pepira Watersheds
}

\author{
Jozrael Henriques Rezende ${ }^{1 *}$, José Salatiel Rodrigues Pires ${ }^{2}$ and Eduardo Mario \\ Mendiondo ${ }^{3}$ \\ ${ }^{l}$ Coordenadoria de Meio Ambiente e Recursos Hídricos; Faculdade de Tecnologia de Jaú; Rua Frei Galvão, s/n ${ }^{o}$; \\ 17212-650; Jaú - SP - Brasil. ${ }^{2}$ Departamento de Hidrobiologia; Universidade Federal de São Carlos; C. P.: 676; \\ 13565-905; São Carlos - SP - Brasil. ${ }^{3}$ Departamento de Hidráulica e Saneamento; Escola de Engenharia de São \\ Carlos; Universidade de São Paulo; Av. Trabalhador São-Carlense, 400; 13566-590; São Carlos - SP - Brasil
}

\begin{abstract}
The aim of this work was to study the influence of natural vegetation in two subwatersheds of the Tietê-Jacaré Water Resources Management Unit in São Paulo State on the pulse of their rivers. In Jacaré-Pepira Subwatershed, having higher remaining cover index, pulses were more predictable and had lower amplitude in the study period, indicating less perturbation of the water body and higher resilience of the aquatic ecosystem. Jacaré-Pepira River specific mean discharge was higher than the $Q_{5 \%}$ calculated through the Hydrologic Regionalization Method for São Paulo State, whereas Jaú River mean discharge was lower than $Q_{5 \%}$. The minimum discharge recorded for JacaréPepira River was higher than $Q_{7.10}$ and equal to $Q_{95 \%}$, whereas for Jaú River this value was practically equal to $Q_{7,10}$ and lower than $Q_{95 \%}$.
\end{abstract}

Key words: discharge, watershed, remaining vegetation cover

\section{INTRODUCTION}

In a hydrological study, the watershed represents the most appropriate unit to qualitatively and quantitatively assess the water and the sediment and nutrient flow. Marques et al (2003), for example, analyzing 16 physical and chemical water variables in the Upper Iguaçu Basin found correlations between water composition and watershed physiographic features. Associations between the physical and drainage characteristics of a watershed and the water volume of a water body, as well as its features, have led several authors to use the concept of watershed as an analog of that of ecosystem when regarded as a study or environmental management unit. The ecosystem is a functional unit in which there is a complex and dynamic interaction of plant, animal (including men) and microorganism communities with the water, soil, air, climate and relief, i.e., the environment (Pires et al., 2002).

A watershed is an open, complex, organized system composed of a large number of interactive compounds capable of exchanging information with their surroundings, adapting the internal structure of the system (Cristofoletti, 2002). As a geomorphological system, a watershed receives energy from climate agents and loses it through discharge and can be described in terms of interdependent variables that oscillate over a

*Author for correspondence: jozrael.rezende@fatec.sp.gov.br 
standard; thus, even when not perturbed by anthropic actions, a watershed is in dynamic equilibrium (Lima, 1989). Any change in energy obtaining or release, or an anthropic or natural alteration in the system, will result in a compensatory change to minimize the caused effect and restore the dynamic equilibrium (Leopold et al., 1964; Gregory, Walling, 1973 apud Lima and Zakia, 2004). The fluctuation scheme of environmental factors in time is known as one of the main components of the environment (Odum, 1988). In aquatic ecosystems, the fluctuation scheme of discharges, and consequently flood quota, represents the system's main strength function, regulating time and space heterogeneity of the river passage (Cruz et al., 1998). Rodrigues et al. (2002) studying the dynamic of the temporal variations on the limnological variables of the Upper Paraná River noticed the importance of the hydrological regime. The discharge needed to preserve the hydrological pulse, sediment and nutrient transportation and wild animal and plant species lifecycle conditions, which is called ecological discharge, must ensure the perturbation rate necessary for the renewing and functioning of ecosystems associated with the water course, keeping its ecological functions in larger and smaller streambeds (Cruz, 2005). The gradual resilience loss in watershed riparian ecosystems is one of the main reasons for the compromising of water resources (Lima, 2005). Forests tend to intercept greater water volumes than cultivated lands or pastures; thus, deforestation considerably affects the pulses of a river. The removal of vegetation cover increases the superficial discharge and the direct water flow to rivers. Draining basins with tillage readily react to rainfall, producing a streamflow much higher than that of basins occupied by natural forest. In the latter, the same water volume is differently processed, since the river discharge slowly increases after downpour, reaching its maximum discharge at a lower level (Lima and Zakia, 2004). Therefore, the hydrological effects of deforestation on watersheds can be noticed through the alteration in the natural pulse or characteristic hydroperiod of a water course. During rainy periods, the lower rainfall interception due to vegetation cover reduction leads to a higher superficial water discharge, increasing the streamflow. During flood periods, such increase reduces the watershed sub-superficial and subterraneous water storage, decreasing, thus, the minimum discharge in drought periods. It is essential to know the intensity of this relationship either to establish appropriate indexes to pay for environmental services in provider-recipient systems or to quantify the need of rehabilitating or restoring the vegetation in a certain watershed for water production.

Natural and artificial aquatic systems are mainly stimulated by short or long fluctuations, natural or induced by men, which are defined as pulses. The magnitude and frequency of such pulses allows the assessment of the hydroperiod characteristic of a river and are fundamental for the prognostic of the consequences of anthropic activities (Tundisi et al., 1999). Environmental factor fluctuations, characterized by amplitude, frequency and predictability, may affect or prevent the species adaptation pattern. Junk and Wantzen (2004) found that predictable pulses favor the adaptation of organisms. The water quantity and quality, as well as the flow scheme of a water course, can be deeply affected by anthropic actions of soil use and occupation in the watershed. When losing natural characteristics, these areas become more vulnerable to perturbations, which otherwise would be normally absorbed.

The hydrological analysis of a river, based on its historical series of discharge and its relationship with the remaining vegetation may contribute to indicate the provided ecosystem services in relation to water production or even the environmental degradation degree in a certain watershed. This work aimed to analyze the hydrological pulse, the discharge permanence curves, and the annual rainfall/discharge relation of two water courses located in contiguous watersheds in the Tietê-Jacaré Water Resources Management Unit (WRMU number 13), from January 1984 to December 1998, based on data collected in two streamflow measurement and two rain gauge stations. The obtained values were related to the discharges predicted by the Hydrologic Regionalization Method for São Paulo State (Liazi et al., 1988) and, qualitatively, to the remaining vegetation cover indexes, as well as to land uses in each watershed.

\section{MATERIALS AND METHODS}

\section{Study area}

The study area comprised Upper Jacaré-Pepira and Jaú River Subwatersheds. They are located in the 
Tietê-Jacaré Water Resources Management Unit (WRMU number 13), which belongs to the watershed of Tietê River. IPT (2000) suggested the division of WRMU number 13 into nine subwatersheds. Upper Jacaré-Pepira Subwatershed has an area of $1,411.08 \mathrm{~km}^{2}$, covering eight municipalities, mainly Brotas $(60.55 \%)$ and Torrinha (13.33\%). Jaú Subwatershed, which has
$467.16 \mathrm{~km}^{2}$, covers five municipalities and its largest areas are in Dois Córregos $(45.61 \%)$ and Jaú (36.36\%) municipalities (IPT, 2000). In Figure 1 , the location of WRMU number 13 is presented relative to the remaining WRMUs defined for São Paulo State, besides a map including the WRMU, its drainage network, and the boundaries of nine subwatersheds.

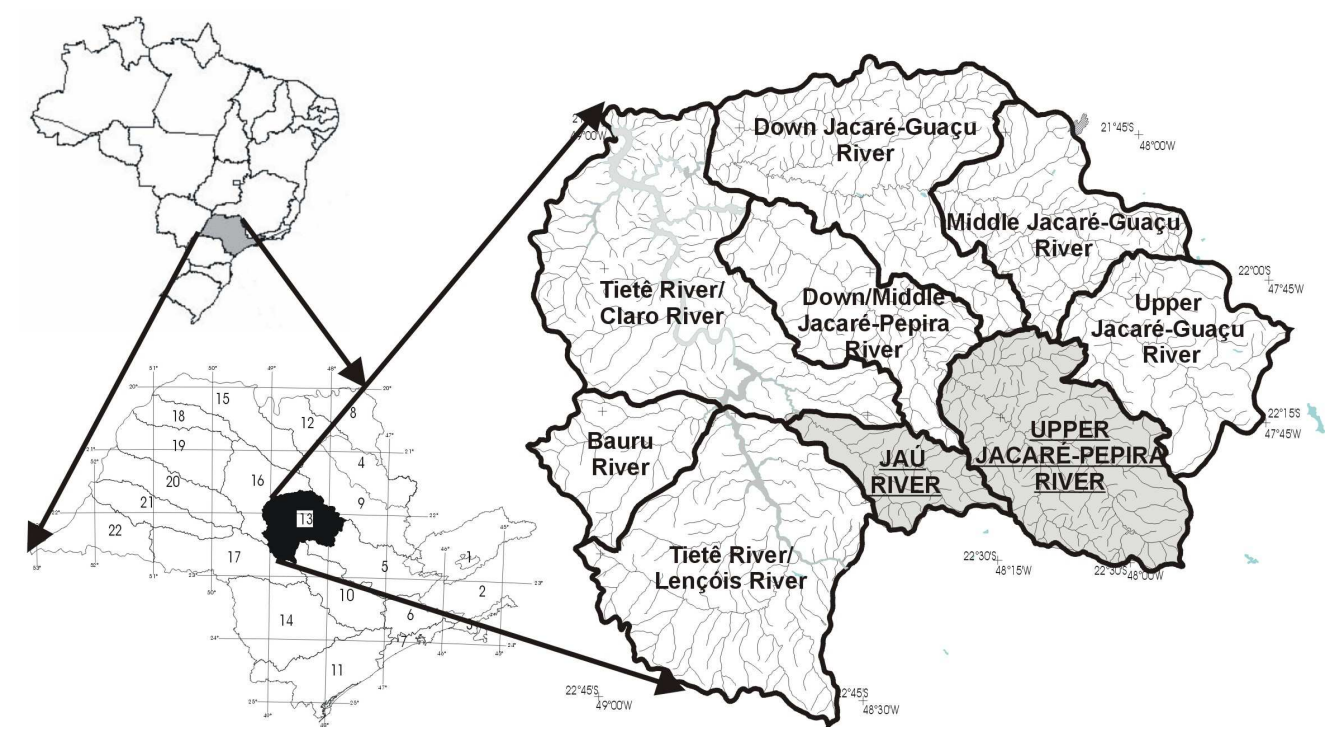

Figure 1 - Location of Tietê-Jacaré Water Resources Management Unit (WRMU number 13) and Upper Jacaré-Pepira and Jaú River Subwatersheds (Fonte: IPT, 2000).

The subwatersheds present "Cwa" climate (Köeppen classification), which is defined as humid subtropical or tropical on high altitudes, with humid summers and dry winters. In normal years, annual rainfall ranges from 1400 to 1500 $\mathrm{mm}$. The rainy period is from October to March, and the rainiest trimester is from December to February. The dry period is between April and September, and the driest trimester, between June and August. Annual mean temperatures range from 21 to $23^{\circ} \mathrm{C}$; maximum means, between 29 and $32^{\circ} \mathrm{C}$ are in January, and minimum means between 11 and $13^{\circ} \mathrm{C}$ in July.

According to IPT (2000), medium hills predominate in these subwatersheds, besides a significant number of scarps in Upper JacaréPepira Subwatershed and a system of elongated small hills and crests in Jaú River Subwatershed. As to declivity classes, the subwatersheds have a similar distribution until 12\%. Upper Jacaré-Pepira
Subwatershed, however, presents a significant declivity percentage higher than $12 \%$. The soil types in Jaú River Subwatershed are mainly red latosol (46.4\%), red-yellow latosol (29.4\%), and red podzol (23.5\%), whereas in Upper JacaréPepira Subwatershed, red-yellow latosol (51.4\%), red-yellow podzol (26.8\%), and sand quartz and regolith soil (18.1\%) predominate (IPT, 2000).

The Institute for Technological Research (IPT, 2000) elaborated a map on soil use and occupation in which the remaining vegetation cover index is calculated for Upper Jacaré-Pepira and Jaú River Subwatersheds as $2.5 \%$ and $0.5 \%$, respectively. The remaining vegetation index in WRMU-13 was $6.67 \%$, according to a survey on the natural vegetation and reforestation and development of a georeferrenced basis for Tietê-Jacaré Watershed (Forest Institute - IF/SMA, 2003), and 7.11\%, according to the report on São Paulo State environmental quality - 2005 (São Paulo State 
Secretary for the Environment - SMA, 2006). These data allowed the simply estimative of 3.5 and $10.5 \%$ for the remaining vegetation index in Jaú River and Upper Jacaré-Pepira Subwatersheds, respectively.

\section{Methodology}

This case study employed secondary rain gauge and streamflow measurement data from the official records of the historical series of the São Paulo State Department of Water and Electric Energy (DAEE). The data were from two rain gauge stations: one in Upper Jacaré-Pepira Subwatershed and another in Jaú River Subwatershed. For the analyses of discharge and permanence curve, the data were from two streamflow measurement stations, one in each river. To compare subwatersheds, all discharge results were transformed into specific discharges, i.e., liters per second per square kilometer of watershed $\left(\mathrm{L} \mathrm{s}^{-1} \mathrm{~km}^{-2}\right)$. Table 1 describes the location and characteristics of the rain gauge and streamflow measurement stations and their respective drainage area upstream to the streamflow measurement sites. The analyzed period was between January 1984 and December 1998, totalizing 15 years. This period was chosen because there were no data available from 1999.

Each river had the maximum and minimum discharges identified. Based on the measured discharges, the mean or reference discharge was calculated, besides the minimum discharge or ensured discharge in $95 \%$ of the observation and recording time $\left(\mathrm{Q}_{95 \%}\right)$, and ensured discharge in $5 \%$ of the observation and recording time $\left(\mathrm{Q}_{5 \%}\right)$. Such values were calculated through the permanence curve, a variation of the diagram of accumulated relative frequencies, in which nonovercoming was substituted for a specific time interval, in which the value of the variable, indicated in the abscissas, was equalized or exceeded (Naghettini and Pinto, 2007). Although there are many concepts or definitions for minimum discharge in worldwide literature, the most employed in Brazil are $\mathrm{Q}_{95 \%}$ and the mean of the lowest daily discharges probable to occur at least once every ten years in seven consecutive days of yearly recording, $\mathrm{Q}_{7,10}$ (Romera e Silva and Leis, 2004). Central tendency (median and mode) and dispersion (standard deviation) measures were also calculated. The results of the hydrological analysis were compared with those obtained by the Hydrologic Regionalization Method of São Paulo State (Liazi et al, 1988), which defined the rainfall/discharge relation for all watersheds in the state based on 219 series of streamflow measurement data, allowing the calculation of the mean and minimum discharges through mathematic simulations. The software and the above-mentioned methodology are available in the internet at the site of Hydric Resources Integrated Management System of São Paulo State (www.sigrh.sp.gov.br). They only require the insertion of the coordinates of the river site (latitude and longitude) and the upstream drainage area.

The percentage of annual rainfall transformed into discharge was assessed by considering the monthly means in the rain gauge stations, including the mean rainfall in the respective subwatershed during the study period.

Table 1- Location of the rain gauge and streamflow measurement stations in Jaú River and Upper Jacaré-Pepira

\begin{tabular}{|c|c|c|c|c|c|}
\hline \multirow[b]{2}{*}{ Rain Gauge Station } & \multicolumn{2}{|c|}{ Subwatershed } & \multirow[b]{2}{*}{$\begin{array}{l}\text { Streamflow } \\
\text { Measuremente Station }\end{array}$} & \multicolumn{2}{|c|}{ Subwatershed } \\
\hline & $\begin{array}{c}\text { Upper } \\
\text { Jacaré-Pepira }\end{array}$ & Jaú & & $\begin{array}{l}\text { Upper Jacaré- } \\
\text { Pepira }\end{array}$ & Jaú \\
\hline Code & D5-078 & D5-022 & Code & $5 \mathrm{D}-028$ & 5D-029 \\
\hline Latitude & $22^{\circ} 17^{\prime}$ & $22^{\circ} 15^{\prime}$ & Latitude & $22^{\circ} 17^{\prime} 31^{\prime \prime}$ & $22^{\circ} 18^{\prime} 02^{\prime \prime}$ \\
\hline Longitude & $48^{\circ} 07^{\prime}$ & $48^{\circ} 27^{\prime}$ & $\begin{array}{l}\text { Longitude } \\
\text { Unstream Subwatershed }\end{array}$ & $48^{\circ} 06^{\prime} 59^{\prime \prime}$ & $48^{\circ} 32^{\prime} 30^{\prime \prime}$ \\
\hline Altitude (m) & 680 & 680 & $\begin{array}{l}\left(\mathrm{km}^{2}\right) \\
\end{array}$ & 442 & 417 \\
\hline
\end{tabular}

Subwatersheds (DAEE, 2000). 


\section{RESULTS AND DISCUSSION}

The rainfall indexes in the watersheds, measured by their respective rain gauge stations during 15 years were similar. Annual mean rainfall was $1416.13 \mathrm{~mm} / \mathrm{year}$ in Jaú River Subwatershed and $1403.24 \mathrm{~mm}$ in Upper Jacaré-Pepira
Subwatershed. The highest rainfall indexes were recorded in the winter and spring for Jaú Subwatershed and in the summer and autumn for Upper Jacaré-Pepira Subwatershed. Figure 2 presents the monthly mean rainfall diagram from January 1984 to December 1998.

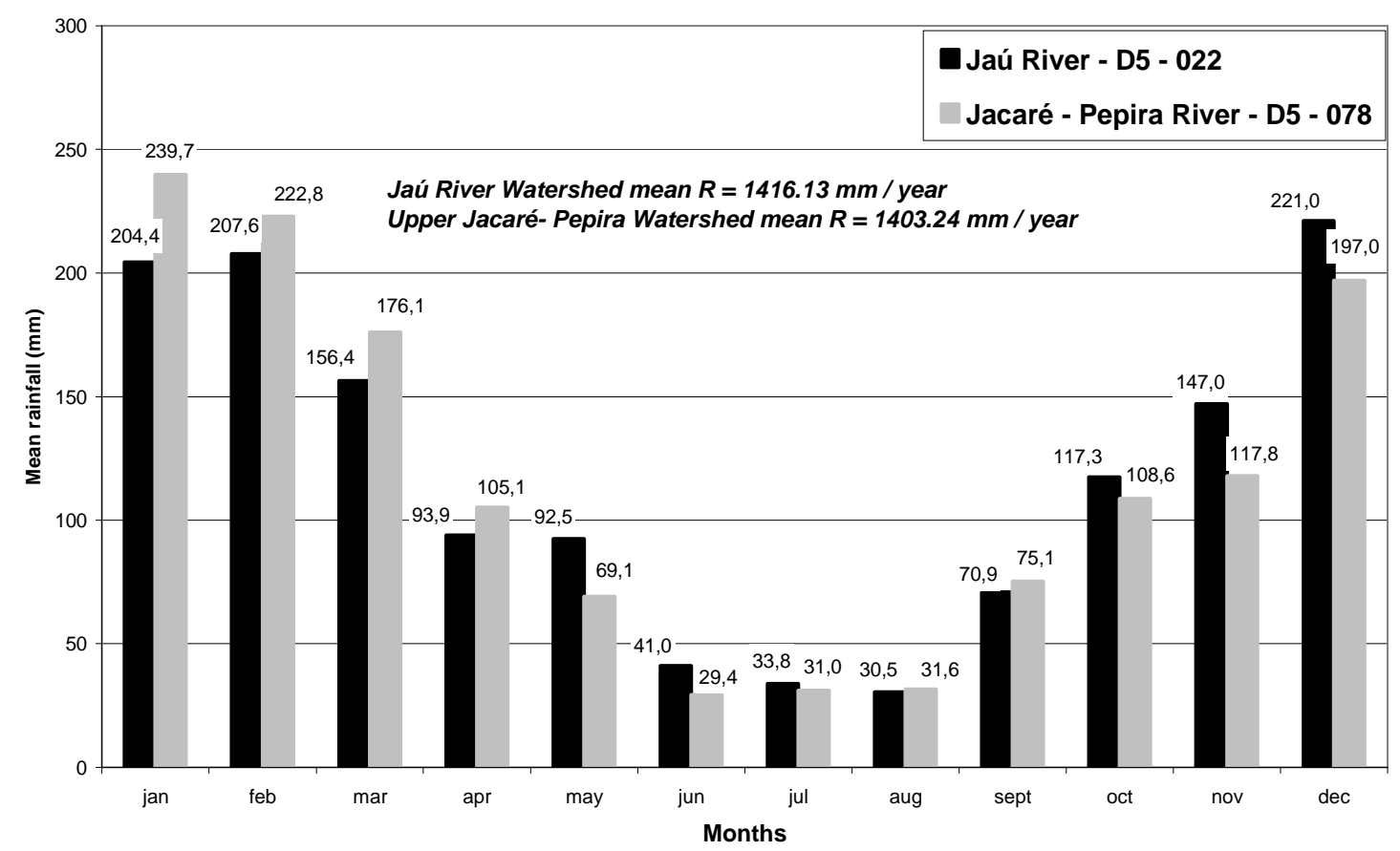

Figure 2 - Monthly mean rainfall diagram from 1984 to 1998 in the rain gauge stations D5-022 and D5-078, located in Jaú River and Jacaré-Pepira Subwatersheds, respectively.

Jaú River presented the lowest specific discharges in the limnophase (drought) and the highest specific discharges in the potamophase (flooding) over the study period. The mean discharges for Jaú and Jacaré-Pepira Rivers were, respectively, 14.10 $\mathrm{L} \mathrm{s}^{-1} \mathrm{~km}^{-2}$ and $17.57 \mathrm{~L} \mathrm{~s}^{-1} \mathrm{~km}^{-2}$; standard deviation, $10.70 \mathrm{~L} \mathrm{~s}^{-1} \mathrm{~km}^{-2}$ and $10.71 \mathrm{~L} \mathrm{~s}^{-1} \mathrm{~km}^{-2}$; median, 11.27 $\mathrm{L} \mathrm{s}^{-1} \mathrm{~km}^{-2}$ and $14.46 \mathrm{~L} \mathrm{~s}^{-1} \mathrm{~km}^{-2}$; and mode, $8.39 \mathrm{~L} \mathrm{~s}^{-1} \mathrm{~km}^{-2}$ and $11.38 \mathrm{~L} \mathrm{~s}^{-1} \mathrm{~km}^{-2}$. The maximum discharge was $165.23 \mathrm{~L} \mathrm{~s}^{-1} \mathrm{~km}^{-2}$ for Jaú River on January 07, 1996, and $125.54 \mathrm{~L} \mathrm{~s}^{-1} \mathrm{~km}^{-2}$ for JacaréPepira River on January 09, 1996. The minimum discharge was $3.36 \mathrm{~L} \mathrm{~s}^{-1} \mathrm{~km}^{-2}$ for Jaú River on December 19, 1985, and $4.45 \mathrm{~L} \mathrm{~s}^{-1} \mathrm{~km}^{-2}$ for JacaréPepira River on November 23, 1998. The hydrogram in Figure 3, including the specific discharge ( $\mathrm{L} \mathrm{s}^{-1} \mathrm{~km}^{-2}$ watershed) in Jacaré-Pepira and Jaú Rivers between January 1984 and December 1998, indicated that Jaú River had higher discharge variation amplitude than JacaréPepira River.

Permanence curves also indicated higher specific maximum discharge and lower specific minimum discharges for Jaú River, relative to Jacaré-Pepira River; however, permanence discharges were higher in Jacaré-Pepira River, i.e. this river ensured higher discharge per square kilometer over time. The permanence curves of the respective rivers in logarithm scale are shown in Figure 4. 


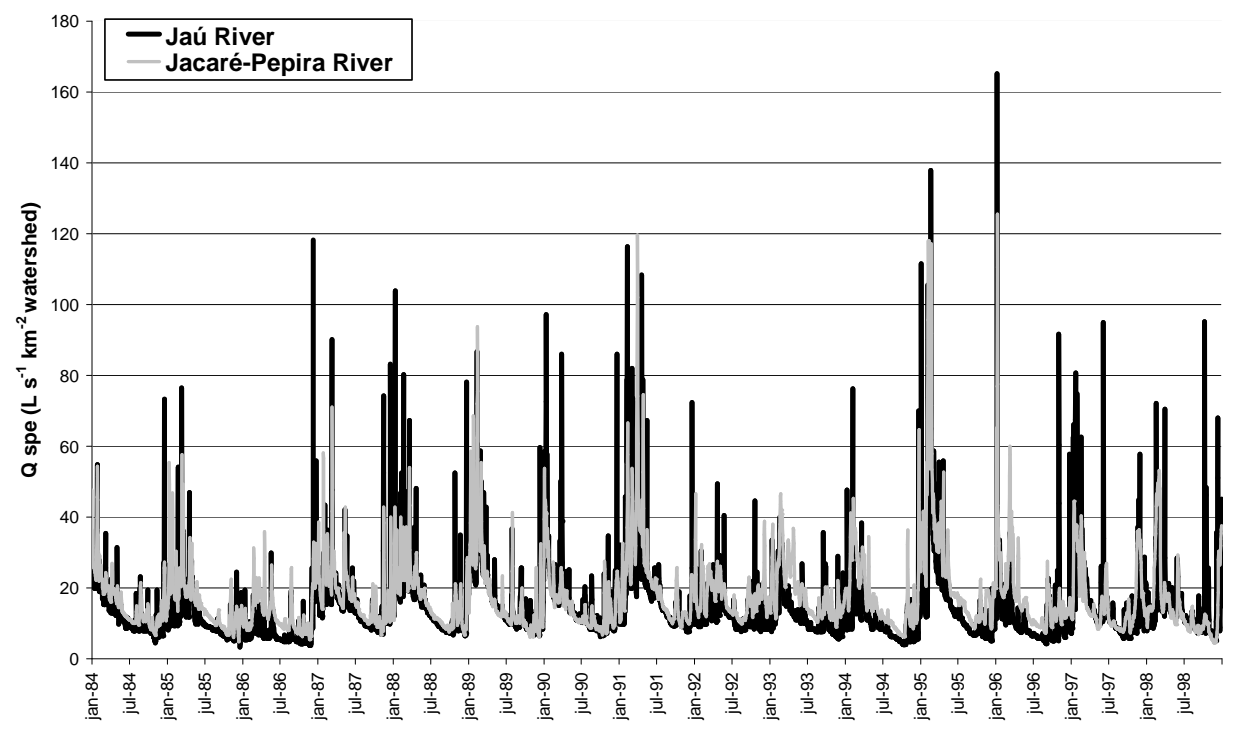

Figure 3 - Specific discharges $\left(\mathrm{L} \mathrm{s}^{-1} \mathrm{~km}^{-2}\right.$ watershed) of Jacaré-Pepira (5D-028) and Jaú (5D-028) Rivers from January 1984 to December 1998.

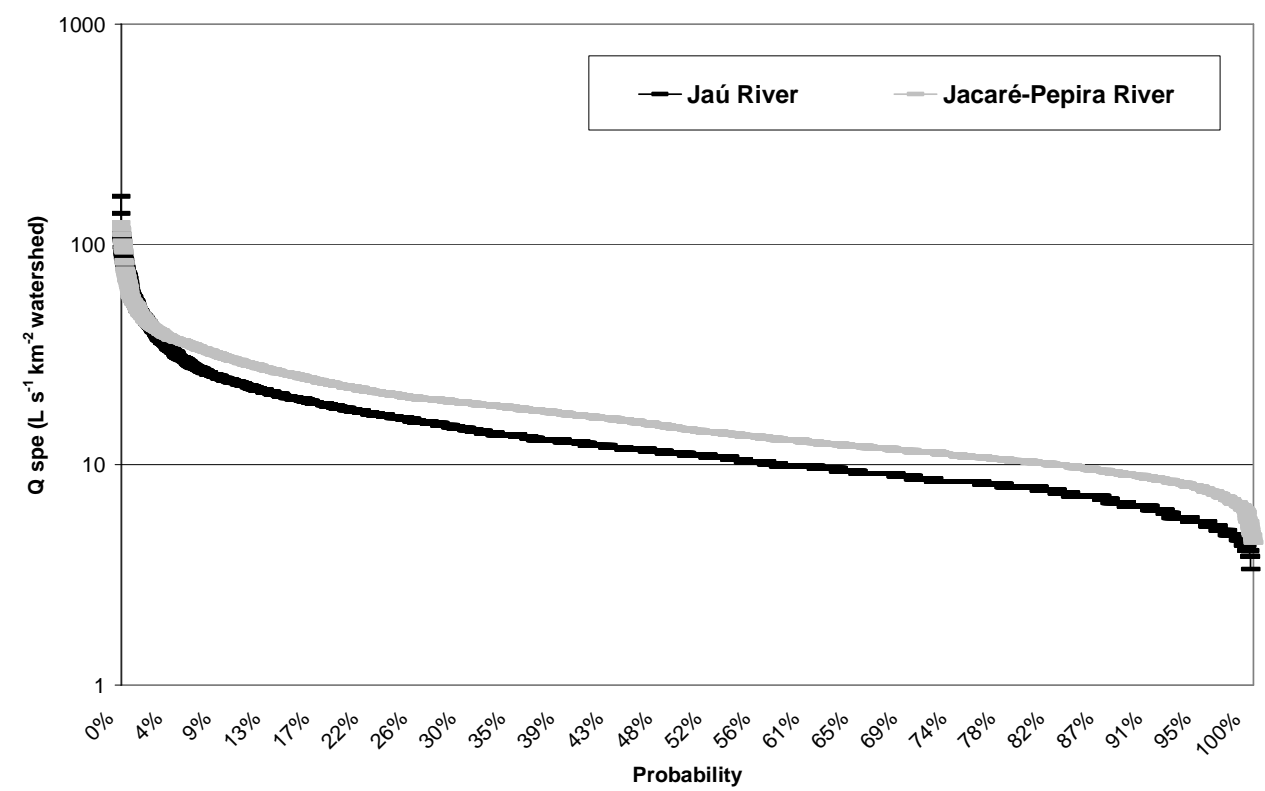

Figure 4 - Permanence curves (Q specific - $\mathrm{L} \mathrm{s}^{-1} \mathrm{~km}^{-2}$ watershed) of Jacaré-Pepira and Jaú Rivers from January 1984 to December 1998.

The mean specific discharge of Jacaré-Pepira River was higher than the 5\% permanence discharge or $\mathrm{Q}_{5 \%}$ (ensured discharge in $5 \%$ of the observation and recording time) calculated by the Hydrologic Regionalization Method. For Jaú River, the mean discharge was lower than $\mathrm{Q}_{5 \%}$. The minimum discharge recorded in the study period for Jacaré-Pepira River was higher than
$\mathrm{Q}_{7,10}$ and equal to $\mathrm{Q}_{95 \%}$. As regards Jaú River, the minimum discharge was practically equal to $\mathrm{Q}_{7,10}$ and lower than $\mathrm{Q}_{95 \%}$. In Table 2, discharge data recorded by the streamflow measurement stations during the study period are compared with the discharges predicted by the Hydrologic Regionalization Method of São Paulo State (Liazi et al, 1988). 
Table 2 - Specific discharges: $\mathrm{Q}_{5 \%}, \mathrm{Q}_{95 \%}, \mathrm{Q}_{7,10}$ and minimum discharge.

\begin{tabular}{cccc}
\hline Method & Discharges & $\begin{array}{c}\text { Jacaré-Pepira River } \\
\left(\mathbf{L ~ s}^{-1} \mathbf{k m}^{-2}\right)\end{array}$ & $\begin{array}{c}\text { Jaú River } \\
\left(\mathbf{L ~ ~ ^ { - 1 }} \mathbf{~ k m}^{-2}\right)\end{array}$ \\
\hline Hydrologic & $\mathrm{Q}^{-2}$ mean & 8.63 & 8.10 \\
Regionalization & $\mathrm{Q}_{5 \%}$ & 17.00 & 15.96 \\
& $\mathrm{Q}_{95 \%}$ & 4.45 & 4.18 \\
& $\mathrm{Q}_{7,10}$ & 3.56 & 3.34 \\
\hline \multirow{3}{*}{ Measured discharge } & $\mathrm{Q}^{2}$ mean & 17.57 & 14.10 \\
$(84-98)$ & $\mathrm{Q}_{5 \%}$ & 36.65 & 31.18 \\
& $\mathrm{Q}_{95 \%}$ & 7.95 & 5.52 \\
& $\mathrm{Q}$ minimum & 4.45 & 3.36 \\
\hline
\end{tabular}

In Jacaré-Pepira River, discharges kept stable although the rainfall indexes tended to decrease over the study period. Table 3 and Figures 5 and 6 indicate the relationship between the annual rainfall measured by the rain gauge stations and annual discharge, as well as rainfall tendencies and rainfall/discharge relation in each subwatershed.

Jacaré-Pepira River pulses in the study period had lower amplitudes, indicating higher equilibrium of environmental factor fluctuations, including amplitude, frequency and predictability in the largest and smallest streambeds. This meant that perturbation in Jacaré-Pepira River was lower and, therefore, more favorable to the renewing and functioning of aquatic ecosystems and the river transition, ensuring the maintenance of its structure, main ecological functions and the system resilience.

Besides vegetation cover and rainfall, declivity and soil types also influence the intensity of superficial discharge, infiltration and water storage in a watershed. Data from the rain gauge stations indicate that the rainfall characteristics over the year and years do not justify the differences found in the hydrologic analysis. Higher declivities, mainly when associated with texture-gradient soils such as red-yellow podzols (Silva et al., 2004), which occupied almost 20\% of Upper JacaréPepira Subwatershed, might increase the intensity of superficial discharge.

Comparing mean declivities and soil types in the subwatersheds, Upper Jacaré-Pepira had higher declivity percentages and greater areas of texturegradient soils. Considering only these aspects, the highest discharge variations, mainly relative to the maximum discharges, should be observed for Jacaré-Pepira River; however, this did not occur.

Table 3 - Discharges and annual rainfall in Jacaré-Pepira and Jaú Subwatersheds.

\begin{tabular}{ccccccc}
\hline \multirow{2}{*}{ Year } & \multicolumn{2}{c}{ Jacaré-Pepira River $\left(\right.$ Area $\left.=\mathbf{4 4 2} \mathbf{~ k m}^{2}\right)$} & \multicolumn{3}{c}{ Jaú River $\left(\right.$ Area $\left.=417 \mathbf{~ k m}^{2}\right)$} \\
\cline { 2 - 7 } & $\begin{array}{c}\text { Discharge } \\
\left(\mathbf{m}^{\mathbf{3}} / \mathbf{y e a r s}\right)\end{array}$ & $\begin{array}{c}\text { Rainfall } \\
\left(\mathbf{m}^{\mathbf{3}} / \mathbf{y e a r s}\right)\end{array}$ & $\begin{array}{c}\text { Discharge } / \\
\text { Rainfall }\end{array}$ & $\begin{array}{c}\text { Discharge } \\
\left(\mathbf{m}^{\mathbf{3}} / \mathbf{y e a r s}\right)\end{array}$ & $\begin{array}{c}\text { Rainfall } \\
\left(\mathbf{m}^{\mathbf{3}} / \mathbf{y e a r s}\right)\end{array}$ & $\begin{array}{c}\text { Discharge / } \\
\text { Rainfall }\end{array}$ \\
\hline 1989 & 255659328 & 679309800 & $37.64 \%$ & 231439680 & 692470200 & $33.42 \%$ \\
1990 & 215492832 & 714537200 & $30.16 \%$ & 215179200 & 604983600 & $35.57 \%$ \\
1991 & 316731168 & 795821000 & $39.80 \%$ & 252979200 & 683004300 & $37.04 \%$ \\
1992 & 242326080 & 595329800 & $40.70 \%$ & 160194240 & 510199500 & $31.40 \%$ \\
1993 & 262533312 & 632811400 & $41.49 \%$ & 162820800 & 578337300 & $28.15 \%$ \\
1994 & 236585664 & 593694400 & $39.85 \%$ & 134377920 & 490266900 & $27.41 \%$ \\
1995 & 348280992 & 749897200 & $46.44 \%$ & 236856960 & 635758200 & $37.26 \%$ \\
1996 & 249658330 & 558732200 & $44.68 \%$ & 142672320 & 494019900 & $28.88 \%$ \\
1997 & 230596848 & 559925600 & $41.18 \%$ & 225201600 & 625708500 & $35.99 \%$ \\
1998 & 210558960 & 480498200 & $43.82 \%$ & 181189440 & 579087900 & $31.29 \%$ \\
\hline
\end{tabular}




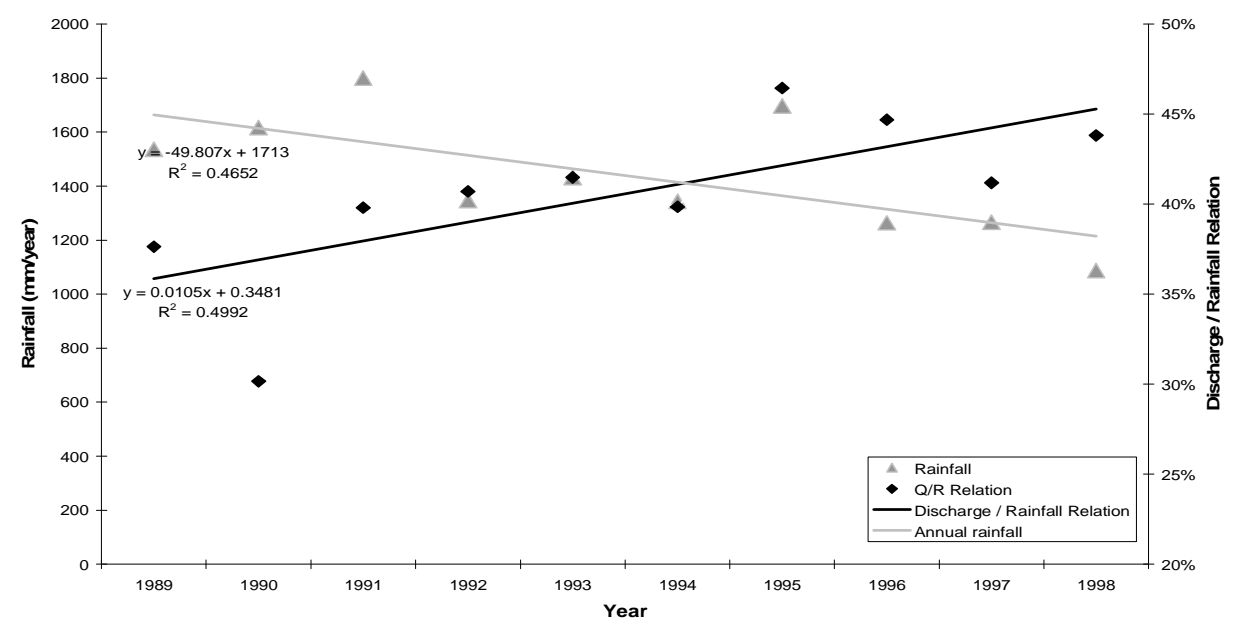

Figure 5 - Jacaré-Pepira River: Discharge/Rainfall Relation (\%) and annual rainfall (mm) from 1989 to 1998.

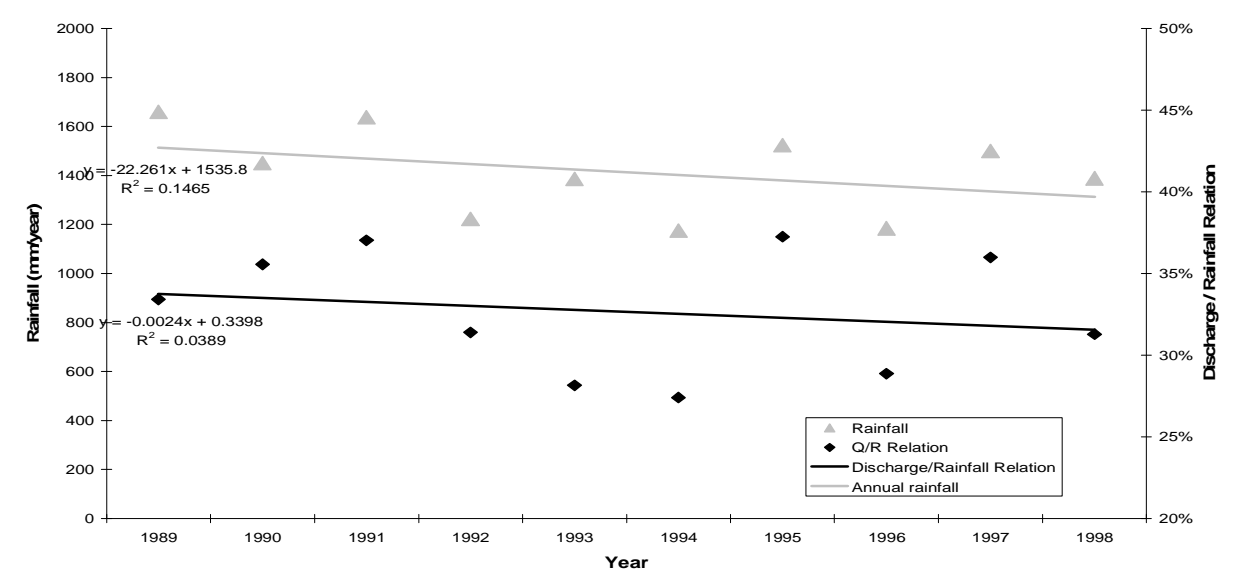

Figure 6 - Jaú River: Discharge/Rainfall Relation (\%) and annual rainfall (mm) from 1989 to 1998.

Upper Jacaré-Pepira Subwatershed had $11 \%$ of its area occupied by extremely sandy soils (sand quartz soils) of high infiltration capacity. As to soil use and occupation, agricultural activities, mainly sugar cane cultivation, predominate in Jaú River Subwatershed, whereas pastures prevail in Upper Jacaré-Pepira Subwatershed. In addition, the remaining vegetation cover index was higher in Upper Jacaré-Pepira Subwatershed, relative to Jaú River Subwatershed, as described in the characterization of the study area.

Borges et al. (2005) studied the soil permeability in Palmital Stream Watershed, i.e., the water capacity to infiltrate into the soil, and observed that the infiltration/discharge relation depended on the soil structure, preparation, erosion and declivity, and was directly related to land use. Permeability is higher in soils under indigenous forest and lower in those under agriculture. In a study case, Borges et al. (2005) demonstrated that the permeability of areas cultivated with sugar cane was higher than that of pastures, especially old and degraded pastures. Table 4 indicates the qualitative influence of the main characteristics of the environmental compounds Rainfall, Soil Type, Declivity and Soil Use on the hydrologic pulse of rivers.

Although many factors could influence the hydroperiod of a river, including rain frequency, intensity and duration; declivity; physical 
characteristics of soils; and land uses in the watershed, the case presented in this work indicated that there was a strong correlation between the vegetation cover index in the subwatersheds and the hydrologic pulse behavior of the rivers.

Table 4 - Qualitative comparison of the influences of environmental compounds in Upper Jacaré-Pepira and Jaú River Subwatersheds on the hydrologic pulse of their rivers.

\begin{tabular}{|c|c|c|c|c|}
\hline $\begin{array}{l}\text { Environmental } \\
\text { compound }\end{array}$ & Characteristic & Evaluation & $\begin{array}{l}\text { Upper Jacaré- } \\
\text { Pepira } \\
\text { Subwatershed }\end{array}$ & $\begin{array}{c}\text { Jaú River } \\
\text { Subwatershed }\end{array}$ \\
\hline Rainfall & $\begin{array}{l}\text { Height, Intensity and } \\
\text { Frequency }\end{array}$ & Similar in both subwatersheds & & \\
\hline \multirow{4}{*}{ Soil Type } & Extremely Sandy & $11 \%$ of Upper Jacaré Subwatershed area & & \\
\hline & Sandy/ Medium & Similar in both subwatersheds & & \\
\hline & Podzol & $58 \%$ of Jaú River Subwatershed area & & \\
\hline & Texture gradient & $20 \%$ of Upper Jacaré Subwatershed area & & \\
\hline \multirow{3}{*}{ Declivity } & Low (until 12\%) & Similar in both subwatersheds & & \\
\hline & Mean (12 to $20 \%)$ & $7 \%$ of Upper Jacaré Subwatershed area & & \\
\hline & High $(>20 \%)$ & $2.7 \%$ of Upper Jacaré Subwatershed area & & \\
\hline \multirow{4}{*}{ Soil use } & Agriculture & $82 \%$ cane in Jaú River Subwatershed & & \\
\hline & Pastures & $77 \%$ of Upper Jacaré Subwatershed area & & \\
\hline & Urbanization & Low in both subwatersheds & & \\
\hline & Remaining Vegetation & Higher in Upper Jacaré subwatershed & & \\
\hline \multicolumn{5}{|c|}{$\begin{array}{l}\text { Higher amplitude and lower predictability of hydrologic pulses. } \\
\text { Lower amplitude and higher predictability of hydrologic pulses. } \\
\text { Similar influence in both subwatersheds. } \\
\text { Not significant in both subwatershed. }\end{array}$} \\
\hline
\end{tabular}

\section{CONCLUSIONS}

Conclusive values are difficult to achieve in the hydrological studies due to the complexity and organization of the watershed system, number of involved variables, lack of recorded data, and weak availability of measurement instruments. Forest removal alters the flows involved in the hydrological cycle of a watershed. The response to these changes greatly varies and is difficult to predict; however, it is necessary to know the relation between the remaining natural vegetation index in a watershed, especially in riparian zones, and the characteristic pulse of a river, not only for ecological and hydrological purposes but also for economic reasons.

The development of models that determine the vegetation index needed to keep or recover the resilience, structure and ecological functions of the system composed of river, riparian zone and drainage area in watersheds may contribute to the orientation and time and space distribution of ecological restoration actions. It may also allow the elaboration of environmental quality indexes by comparing the ideal vegetation and discharge situation with the existent conditions in the watershed, serving as reference to assess the provided environmental services related to water production.

As regards the present case, studies must continue in order to evaluate vegetation cover and soil use alterations in the subwatersheds during the last decade, as well as the hydrological behavior of their rivers. In the last decade, there has been an increase in sugar cane cultivation areas throughout Upper Jacaré-Pepira Subwatershed and in the headwaters of Jaú River Subwatershed for the substitution of pastures and other cultures.

\section{RESUMO}

Este trabalho discute a influência da cobertura vegetal natural remanescente de duas sub-bacias hidrográficas, localizadas na Unidade de Gerenciamento de Recursos Hídricos Tietê Jacaré, estado de São Paulo, no pulso dos rios de cada uma delas. A sub-bacia hidrográfica do rio Jacaré-Pepira, com maior índice de cobertura remanescente, apresentou pulsos mais previsíveis e de menor amplitude no período estudado, indicando menor perturbação do corpo hídrico e maior resiliência do ecossistema aquático. Constatou-se que a vazão média específica do rio 
Jacaré-Pepira no período foi maior que a $\mathrm{Q}_{5 \%}$ calculada pelo método de Regionalização Hidrológica do Estado de São Paulo, enquanto que para o rio Jaú a vazão média foi menor que a respectiva $\mathrm{Q}_{5 \%}$. A vazão mínima registrada no período para o rio Jacaré-Pepira foi maior que a $\mathrm{Q}_{7,10}$ e igual a $\mathrm{Q}_{95 \%}$. e para o rio Jaú a vazão mínima registrada no período foi praticamente igual a $\mathrm{Q}_{7,10}$ e menor que $\mathrm{Q}_{95 \%}$.

\section{REFERENCES}

Borges, M. J.; Pissarra, T. C. T.; Valeri, S. V.; Okumura, E. M. (2005), Reflorestamento compensatório com vistas à retenção de água no solo da bacia hidrográfica do Córrego Palmital, Jaboticabal, SP. Scientia forestalis, 69, p.93-103

Christofoletti, A. (2002), Sistemas e Modelos. InModelagem de sistemas ambientais. ed. Editora Edgard Blücher, São Paulo, pp 1-18

Cruz, R.C.; Porto, M.L. and Silveira, G.L. (1998), Relação entre Padrões e Processos em Pequenas Bacias Hidrográficas: a Interface entre Ecologia de Paisagem e Hidrologia através do Geoprocessamento e da Geometria Fractal. In: Anais. $1^{\circ}$ Fórum de GeoBio-Hidrologia, Estudos em Vertentes e MicroBacias Hidrográficas. Curitiba, UFPR, v.1, pp. 184189

Cruz, R.C. (2005), Prescrição de vazão ecológica: Aspectos ambientais e técnicos para bacias com carência de dados. Tese (Doutorado), Universidade Federal do Rio Grande do Sul. Porto Alegre

Departamento de Água e Energia Elétrica - DAEE (2000), Sistema de informações para o Gerenciamento de Recursos Hídricos do Estado de São Paulo. Disponível em CD.

Instituto de Pesquisas Tecnológicas - IPT. (2000), Diagnóstico da situação atual dos recursos hídricos e estabelecimento de diretrizes técnicas para a elaboração do plano da bacia hidrográfica do Tietê Jacaré. São Paulo: (Relatório IPT n 40674/00)

Instituto Florestal - Secretaria do Meio Ambiente - IFSMA (2003), Levantamento da vegetação natural e reflorestamento e constituição de base georreferenciada da Bacia Hidrográfica do TietêJacaré. Relatório Técnico: Contrato FEHIDRO $\mathrm{n}^{\circ}$. 094/2002

Junk, W.J.; Wantzen, K.M. (2004), The Flood Pulse Concept: New Aspects, Approaches and Applications - An Update. In: Welcomme, R.L.; Petr, T. (eds.) Proceedings of the Second International Symposium on the Management of Large Rivers for Fisheries. Volume II. Bangkok, Thailand: FAO Regional Officefor Asia and the Pacific. RAP Publication 2004/17, pp. $117-140$
Liazi, A.; Conejo, J. L.; Palos, J. C. F.; Cintra, P. S. (1988), Regionalização Hidrológica no estado de São Paulo. Revista Águas e Energia Elétrica DAEE, 5, 14, 4-10.

Lima, W. P (2005), Floresta natural protege e estabiliza os recursos hídricos. Visão Agrícola, Piracicaba, 4, 30-33

Lima, W.P. (1989), Função hidrológica da mata ciliar. In- Simpósio sobre Mata Ciliar, Ed. Fundação Cargill: pp.25-42

Lima, W.P.; Zakia, M. J. B. (2004), Hidrologia de matas ciliares. Disponível em: http://www.ipef.br. Acesso em 19 de jun. de 2006

Marques, P. H. C; Oliveira, H. T and Machado, E. C. (2003), Limnological Study of Piraquara (Upper Iguaçu Basin): Spatiotemporal Variation of Physical and Chemical Variables and Watershed Zoning. Brazilian Archives of Biology end Technology, 46, 3, 383-394.

Naghettini, M; Pinto, E. J. A. (2007). Análise preliminar de dados hidrológicos. In- Hidrologia Estatística, Ed. CPRM, Belo Horizonte, pp. 17-35

Odum, E. P. (1988), Ecologia. Tradução de Rios, R. I.; Tribe, C. J. Editora Guanabara, Rio de Janeiro.

Pires, J. S. R.; Santos, J. E.; Del Prette, M. E. (2002), A utilização do conceito de bacia hidrográfica para a conservação dos recursos naturais. In- Shiavetti, A.; Camargo, A (Orgs). Conceito de Bacia Hidrográfica: Teorias e Aplicaçõe. ed. Editus/UESC, Ilhéus, pp. 113

Rodrigues, L. C; Train, S.; Roberto, M. C and Paggioro, T. A. (2002) Seasonal Fluctuation of Some Limnological Variables on a Floodplain Lake (Patos lagoon) of the Upper Paraná River, Mato Grosso do Sul State, Brazil. Brazilian Archives of Biology end Technology, 45, 4, 499-513.

Romera e Silva, P. A.; Leis, W. M. S. V. (2004), Curso de capacitação em Recursos Hídricos. Fundação Centro Tecnológico de Hidráulica - FCTH/USP. Contrato Fehidro ${ }^{\circ}$ 05/03

Secretaria do Meio Ambiente - SMA (2006), Relatório de Qualidade Ambiental do Estado de São Paulo 2006. Disponível em: http://www.ambiente.sp.gov.br Acesso em Acesso em 14 de jun. de 2006.

Silva, A. M.; Schulz, H. E.; Camargo, P. B. (2004), Erosão e hidrossedimentologia em bacias hidrográficas, ed RiMa, São Paulo

Tundisi, J. G.; Tundisi T. M.; Rocha, O. (1999), Ecossistemas de águas interiores e Limnologia de águas interiores. Impactos, conservação e recuperação de ecossistemas aquáticos. In- Rebouças, A. C.; Braga, B.; Tundisi, J. G. Águas doces no Brasil. ed. Escrituras, São Paulo, pp.195-225.

Received: December 23, 2008; Revised: May 21, 2009; Accepted: March 30, 2010. 